\title{
Improved Thermochemical Energy Storage Behavior of Manganese Oxide by Molybdenum Doping
}

\author{
Javier Moya ${ }^{1}$, Javier Marugán ${ }^{1}\left(\mathbb{D}\right.$, María Orfila ${ }^{1}\left(\mathbb{D}\right.$, Manuel Antonio Díaz-Pérez ${ }^{2} \mathbb{D}$ and \\ Juan Carlos Serrano-Ruiz $2, * \mathbb{0}$
}

1 Department of Chemical and Environmental Technology, Universidad Rey Juan Carlos, C/Tulipán s/n, 28933 Móstoles, Madrid, Spain; j.moyas@alumnos.urjc.es (J.M.); javier.marugan@urjc.es (J.M.); maria.orfila@urjc.es (M.O.)

2 Materials and Sustainability Group, Department of Engineering, Universidad Loyola Andalucía, Avda. De las Universidades s/n, 41704 Dos Hermanas, Seville, Spain; madiaz@uloyola.es

* Correspondence: jcserrano@uloyola.es

check for updates

Citation: Moya, J.; Marugán, J.; Orfila, M.; Díaz-Pérez, M.A.; Serrano-Ruiz, J.C. Improved Thermochemical Energy Storage Behavior of Manganese Oxide by Molybdenum Doping. Molecules 2021, 26, 583. https://doi.org/10.3390/ molecules 26030583

Academic Editor: Guanglin Xia Received: 26 November 2020

Accepted: 21 January 2021

Published: 22 January 2021

Publisher's Note: MDPI stays neutral with regard to jurisdictional claims in published maps and institutional affiliations.

Copyright: (c) 2021 by the authors. Licensee MDPI, Basel, Switzerland. This article is an open access article distributed under the terms and conditions of the Creative Commons Attribution (CC BY) license (https:// creativecommons.org/licenses/by/ $4.0 /)$.

\begin{abstract}
To improve the thermochemical energy storage (TCS) behavior of $\mathrm{Mn}_{2} \mathrm{O}_{3}$, several $\mathrm{Mn}-\mathrm{Mo}$ oxides with varying amounts of $\mathrm{MoO}_{3}(0-30 \mathrm{wt} \%)$ were prepared by a precipitation method. The physico-chemical properties of the solids were studied by $\mathrm{N}_{2}$ adsorption-desorption, $\mathrm{X}$-ray diffraction (XRD), scanning electron microscopy (SEM), and $\mathrm{H}_{2}$-temperature-programmed reduction (TPR), while their TCS behavior was determined by thermogravimetric analysis coupled with differential scanning calorimetry (TGA-DSC). Apart from $\mathrm{Mn}_{2} \mathrm{O}_{3}$ and $\mathrm{MoO}_{3}$ phases, XRD revealed a mixed $\mathrm{MnMoO}_{4}$ phase for $\mathrm{MoO}_{3}$ loadings equal or higher than $1.5 \mathrm{wt} \%$. All samples showed a wellformed coral-like surface morphology, particularly those solids with low $\mathrm{MoO}_{3}$ contents. This coral morphology was progressively decorated with compact and Mo-enriched $\mathrm{MnMoO}_{4}$ particles as the $\mathrm{MoO}_{3}$ content increased. TPR revealed that the redox behavior of $\mathrm{Mn}_{2} \mathrm{O}_{3}$ was significantly altered upon addition of Mo. The TCS behavior of $\mathrm{Mn}_{2} \mathrm{O}_{3}$ (mostly oxidation kinetics and redox cyclability) was enhanced by addition of low amounts of $\mathrm{Mo}\left(0.6\right.$ and $\left.1.5 \% \mathrm{MoO}_{3}\right)$ without significantly increasing the reduction temperature of the solids. The coral morphology (which facilitated oxygen diffusion) and a smoother transition from the reduced to oxidized phase were suggested to be responsible for this improved TCS behavior. The samples containing 0.6 and $1.5 \mathrm{wt} \%$ of $\mathrm{MoO}_{3}$ showed outstanding cyclability after 45 consecutive reduction-oxidation cycles at high temperatures $\left(600-1000{ }^{\circ} \mathrm{C}\right)$. These materials could potentially reach absorption efficiencies higher than $90 \%$ at concentration capacity values typical of concentrated solar power plants.
\end{abstract}

Keywords: thermochemical energy storage; Mn-Mo mixed oxides; reducibility; redox cyclability; oxidation kinetics

\section{Introduction}

Global energy consumption is increasing by the ever-growing demand of energy from developing countries, and renewable energy sources are becoming more important in covering this demand [1]. Among the renewable energy technologies available today, concentrated solar power (CSP), with an installed generation capacity of 4.4 GW in 2014 [2], is particularly relevant. As is common to renewable energies, the discontinuous nature of solar energy makes necessary the development of storage technologies to overcome the negative effects of transitory weather conditions, to modulate low-to-high energy gaps, and to achieve continuous $24 \mathrm{~h}$ electricity production [3,4]. In the case of CSP, the development of efficient thermal energy storage (TES) systems is particularly important. Three different TES approaches based on sensible, latent, and thermochemical heat are currently available. Among them, thermochemical energy storage (TCS, i.e., the utilization of a reversible chemical process to store thermal energy) holds great promise for future CSP plants owing to its higher energy density and discharge temperatures compared to sensible- and latent 
heat-based approaches. While high discharge temperatures allow increasing the efficiency of steam turbines, high energy densities are important for reducing the size of the storage tank facilities and, therefore, decreasing the capital expenses of the plant $[3,5,6]$. TCS allows solar thermal energy to be stored (and subsequently released) in form of chemical energy by promoting a high-temperature reversible chemical process. Thus, a highly endothermic reaction is used for the charging step, while the reverse exothermic process allows releasing energy in the discharge step while closing the chemical loop for a new cycle. As chemical bonds are broken and formed during the process, large amounts of energy are potentially absorbed/released within each cycle $[7,8]$.

A good number of solids including hydrides, hydroxides, carbonates, and oxides have been tested as TCS materials. Among them, metal oxides are particularly interesting because of their high reaction temperatures and the utilization of oxygen as a reactant, which opens the possibility of using air as a working fluid and thus simplify gas storage installations [5,6,9]. General Atomics conducted a comprehensive analysis on the main TCS technologies with potential to be used in CSP plants, covering a large number of metal oxides [10]. This study identified cobalt (II,III) oxide $\left(\mathrm{Co}_{3} \mathrm{O}_{4}\right)$ as the most promising TCS material in virtue of its superior energy density, high conversion temperature, and good cyclability. Despite its demonstrated thermal stability [11], $\mathrm{Co}_{3} \mathrm{O}_{4}$ is costly and toxic and, therefore, less harmful and cheaper alternatives are required. In this sense, other oxides such as $\mathrm{CuO}$ have shown superior energy density and reaction temperatures [11]. However, the reduction temperature of $\mathrm{CuO}$ is close to the melting point of its reduced form $\left(\mathrm{Cu}_{2} \mathrm{O}\right)$, which increases the risk of sintering and loss of activity [11-13]. Barium oxide $(\mathrm{BaO})$, despite having a reaction temperature well suited for superheated steam cycles, suffers from poor thermal stability and high sensitivity to water and $\mathrm{CO}_{2}$ traces (leading to inactive hydroxide or carbonate materials, respectively) [6,11,14-16].

Manganese (III) oxide $\left(\mathrm{Mn}_{2} \mathrm{O}_{3}\right)$ has been widely studied as a TCS material [17] in virtue of the following charge and discharge processes:

$$
\begin{gathered}
\text { Charge (reduction): } 6 \mathrm{Mn}_{2} \mathrm{O}_{3} \rightarrow 4 \mathrm{Mn}_{3} \mathrm{O}_{4}+\mathrm{O}_{2} \\
\text { Discharge (oxidation): } 4 \mathrm{Mn}_{3} \mathrm{O}_{4}+\mathrm{O}_{2} \rightarrow 6 \mathrm{Mn}_{2} \mathrm{O}_{3}
\end{gathered}
$$

Despite its low cost and abundancy, $\mathrm{Mn}_{2} \mathrm{O}_{3}$ suffers from a number of drawbacks. Thus, the reduced form of $\mathrm{Mn}_{2} \mathrm{O}_{3}\left(\mathrm{Mn}_{3} \mathrm{O}_{4}\right)$ has been reported to show very low re-oxidation rates, which leads to incomplete regeneration of the original oxide and poor cycling behavior $[10,17]$. These limitations can be overcome by enhancing the redox behavior of Mn via formation of a mixed oxide [13,18-20]. Among the large number of combinations tested, Mn-Fe mixed oxides have shown good oxidation behaviors and faster re-oxidation rates compared to $\mathrm{Mn}_{2} \mathrm{O}_{3}$. However, these improvements are achieved at the expense of increasing the reduction (charge) temperature of the resulting mixed oxides, which complicates the CSP process $[8,10,13,21,22]$. To overcome this issue, we suggest herein, for the first time, the utilization of Mo in replacement of Fe to improve the TCS properties of $\mathrm{Mn}_{2} \mathrm{O}_{3}$ without significantly increasing the reduction temperature of the solids. Mo was selected because it possesses very similar size (ionic radius of $\mathrm{Mo}^{6+}: 73 \mathrm{pm}$ ) compared to $\mathrm{Mn}^{3+}(72 \mathrm{pm})$, thereby facilitating the substitution process. In fact, Mn and Mo have been previously described to form stable mixed-oxide phases such as $\mathrm{MoMnO}_{4}$ and $\mathrm{Mo}_{3} \mathrm{Mn}_{2} \mathrm{O}_{8}[23,24]$, and $\mathrm{Mo}^{6+}$ has been reported to substitute $\mathrm{Mn}^{3+}$ by forming six-fold octahedral coordination compounds [25-27]. Having this in mind, we herein analyzed the suitability of Mo-doped $\mathrm{Mn}_{2} \mathrm{O}_{3}$ as TCS materials. Several Mo-doped manganese oxides with varying loadings of Mo were prepared by a precipitation method. The textural, structural, morphological, redox, and thermochemical properties of these materials were characterized by $\mathrm{N}_{2}$ adsorption-desorption, X-ray diffraction (XRD), scanning electron microscopy (SEM), $\mathrm{H}_{2}$-temperature-programmed reduction (TPR), and thermogravimetric analysis coupled with differential scanning calorimetry (TGA-DSC), respectively. 


\section{Materials and Methods}

\subsection{Materials Preparation}

Mn-Mo solids with varying $\mathrm{MoO}_{3}$ loadings $(0,0.6,1.5,8.7,12$, and $31 \mathrm{wt} \%$, denoted as $\mathrm{X} \% \mathrm{MoO}_{3}$ with $\mathrm{x}$ indicating the $\mathrm{MoO}_{3}$ loading) were prepared by a precipitation method. Briefly, appropriate amounts of the precursors $\mathrm{Mn}\left(\mathrm{NO}_{3}\right)_{2} \cdot 4 \mathrm{H}_{2} \mathrm{O}$ (Scharlau, Barcelona, Spain, $>98.5 \%$ ) and $\left(\mathrm{NH}_{4}\right)_{6} \mathrm{Mo}_{7} \mathrm{O}_{24} \cdot 4 \mathrm{H}_{2} \mathrm{O}$ (Sigma-Aldrich, St. Louis, MO, USA, >99.0\%) were dissolved in $250 \mathrm{~mL}$ of distilled water and stirred for $30 \mathrm{~min}$. A $2.5 \mathrm{M} \mathrm{NaOH}$ aqueous solution was subsequently added dropwise until $\mathrm{pH}=12$ was reached. This $\mathrm{pH}$ was maintained for $4 \mathrm{~h}$ while stirring, and the as-obtained precipitate was subsequently filtered and cleaned three times with $500 \mathrm{~mL}$ of Milli- $\mathrm{Q}^{\circledR}$ water. The as-obtained solid was subsequently dried at $100{ }^{\circ} \mathrm{C}$ overnight, ground to fine powders with an agate mortar, calcined at $750{ }^{\circ} \mathrm{C}$ under static air for $4 \mathrm{~h}\left(10{ }^{\circ} \mathrm{C} / \mathrm{min}\right.$ heating rate), ground again, and finally stored for analysis.

In addition, the $100 \% \mathrm{MoO}_{3}$ sample was prepared by directly calcining $\left(\mathrm{NH}_{4}\right)_{6} \mathrm{Mo}_{7} \mathrm{O}_{24}$. $4 \mathrm{H}_{2} \mathrm{O}$ at $350^{\circ} \mathrm{C}$ for $4 \mathrm{~h}$. The calcined sample was ground in an agate mortar. This material was not characterized in full since it sublimates at $600{ }^{\circ} \mathrm{C}$ [28].

\subsection{Materials Characterization}

TPR experiments (ca. $45 \mathrm{mg}$ of sample) were performed on a Micromeritics Autochem II within a temperature range of $60-900{ }^{\circ} \mathrm{C}\left(10^{\circ} \mathrm{C} / \mathrm{min}\right.$ heating rate $)$ under flowing (50 $\mathrm{mL} / \mathrm{min}$ ) $10 \% \mathrm{H}_{2} / \mathrm{Ar}$. The specific surface areas of the samples were obtained by adsorption-desorption of $\mathrm{N}_{2}$ at $77 \mathrm{~K}$ on a Micromeritics ASAP 2020 following the multipoint Brunauer-Emmett-Teller (BET) method. The samples were previously degassed at $300{ }^{\circ} \mathrm{C}$ under vacuum for $100 \mathrm{~min}$. Powder XRD analyses were carried out on a Rigaku UltimaIV diffractometer employing $\mathrm{CuK} \alpha$ radiation and a scanning rate of $2^{\circ} / \mathrm{min}$. SEM observations were carried out on a Hitachi S5200 microscope, and samples were used without any further modification. Inductively coupled plasma atomic emission spectroscopy (ICP-AES) was used to determine the actual oxide content of the different samples. This measurement was made on a Varian Vista AX spectrometer, and samples were previously dissolved in $5 \mathrm{~mL}$ of aqua regia $\left(\mathrm{HNO}_{3}: \mathrm{HCl}, 1: 3\right.$ in volume).

\subsection{Thermal Cyclability}

The TCS behavior of the samples upon repetitive thermal cycles was studied by TGADSC on a TA Instruments SDT Q-600 device. The samples (18-22 mg) were placed on $90 \mu \mathrm{L}$ alumina crucibles. At least 10 redox cycles were performed over each sample under flowing air (50 mL/min, oxidation) at temperatures ranging from 600 to $1000{ }^{\circ} \mathrm{C}$.

\section{Results and Discussion}

\subsection{Thermodynamic Study}

We considered the following process to describe the thermochemical behavior of Mn-Mo mixed oxides:

$$
\mathrm{Mo}_{\mathrm{x}} \mathrm{Mn}_{2-2 \cdot \mathrm{x}} \mathrm{O}_{3} \rightarrow \mathrm{Mo}_{\mathrm{x}} \mathrm{Mn}_{2-2 \cdot \mathrm{x}} \mathrm{O}_{2.67-0.67 \cdot \mathrm{x}}+\frac{0.33+0.67 \cdot \mathrm{x}}{2} \mathrm{O}_{2}
$$

The process was theoretically studied using the HSC Chemistry 6.1 software @Outotec Research Oy. The dependence of the Gibbs free energy of reaction $\left(\Delta \mathrm{G}_{\mathrm{r}}^{\mathrm{T}}\right)$ with the temperature was studied. This energy was calculated from the standard enthalpies $\left(\Delta \mathrm{H}_{\mathrm{f}}{ }_{\mathrm{f}}\right)$ and entropies $\left(\Delta S_{\mathrm{f}}^{\circ}\right)$ of formation for the pure oxides $\left(\mathrm{Mn}_{2} \mathrm{O}_{3}\right.$ and $\left.\mathrm{MoO}_{3}\right)$ and the temperature dependence of its specific heat $(\mathrm{Cp}(\mathrm{T}))$. The data for the mixed oxide samples were obtained by interpolating pure oxides at their corresponding content (Figure 1), and the results are summarized in Table 1 . As shown in Table 1 and Figure 1 , the reduction temperature increased significantly with the amount of Mo in the mixed oxide. This theoretical evaluation assumed the formation of a mixed oxide phase having intermediate physical-chemical properties mixed as compared to the pure manganese or molybdenum oxides. 


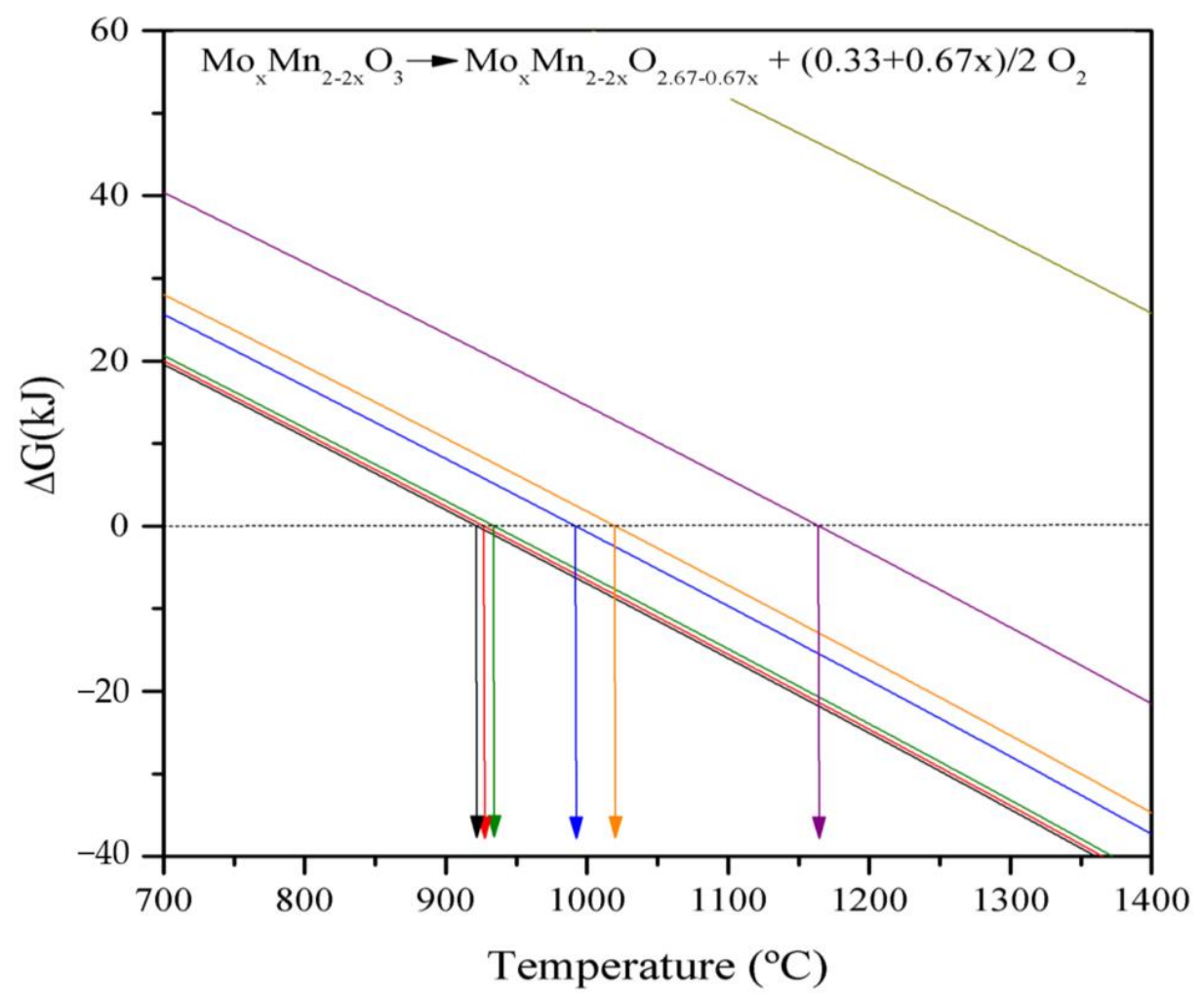

Figure 1. Theoretical evaluation of the reduction temperature of the samples. From bottom to top — $: 0 \% \mathrm{MoO}_{3} ;-: 0.6 \% \mathrm{MoO}_{3} ;-: 1.5 \% \mathrm{MoO}_{3} ;-: 8.7 \% \mathrm{MoO}_{3} ;-: 12 \% \mathrm{MoO}_{3} ;-: 31 \% \mathrm{MoO}_{3}$; - $100 \% \mathrm{MoO}_{3}$.

Table 1. Theoretical reduction temperature and specific surface area of the samples studied herein.

\begin{tabular}{ccccc}
\hline Sample & $\begin{array}{c}\text { Theoretical } \mathbf{M o O}_{3} \\
\text { Content }(\mathbf{w t} \%)\end{array}$ & $\begin{array}{c}\text { Actual } \mathbf{M o O}_{3} \\
\text { Content }(\mathbf{w t} \%)\end{array}$ & $\begin{array}{c}\text { Theoretical } \\
\text { Temperature of } \\
\text { Reduction }\left({ }^{\circ} \mathbf{C}\right)\end{array}$ & $\begin{array}{c}\text { BET Surface } \\
\text { Area }\left(\mathbf{m}^{2} / \mathbf{g}\right)\end{array}$ \\
\hline $0 \% \mathrm{MoO}_{3}$ & 0 & 0.00 & 922 & 6.17 \\
$0.6 \% \mathrm{MoO}_{3}$ & 0.6 & 0.62 & 927 & 3.03 \\
$1.5 \% \mathrm{MoO}_{3}$ & 1.5 & 1.52 & 934 & 2.98 \\
$8.7 \% \mathrm{MoO}_{3}$ & 8.5 & 8.70 & 992 & 5.65 \\
$12 \% \mathrm{MoO}_{3}$ & 12 & 12.2 & 1019 & 3.54 \\
$31 \% \mathrm{MoO}_{3}$ & 30 & 31.0 & 1164 & 2.03 \\
$100 \% \mathrm{MoO}_{3}$ & 100 & 100 & $>1400$ & - \\
\hline
\end{tabular}

\subsection{Physical-Chemical Characterization}

The morphology, composition, and crystal structure of the samples were characterized by a number of techniques. As shown in Table 1, the actual Mo contents of the samples (determined by ICP-AES) were very similar to the nominal values. All the samples showed low BET surface areas and low porosity, probably as a result of the high calcination temperature used herein $\left(750^{\circ} \mathrm{C}\right)$. These samples are expected to undergo sintering during thermal cycling, decreasing the surface area below the detection limit of the adsorption device.

Figure 2a shows the XRD patterns of all the oxides under study. The diffractograms revealed the presence of a cubic $\mathrm{Mn}_{2} \mathrm{O}_{3}$ crystalline phase (ICDD: 00-002-0896) for all the samples except for $100 \% \mathrm{MoO}_{3}$. The XRD pattern of this cubic $\mathrm{Mn}_{2} \mathrm{O}_{3}$ crystalline phase was characterized by an intense diffraction peak at $32.9^{\circ}$. As shown in Figure $2 b$, the addition of small amounts of $\mathrm{Mo}\left(0.6 \% \mathrm{MoO}_{3}\right)$ resulted in a very slight shifting of this peak to higher diffraction angles. However, no gradual angle shifting was observed as the amount of Mo increased above $0.6 \% \mathrm{MoO}_{3}$. Given the very similar ionic radii of $\mathrm{Mn}^{3+}$ and $\mathrm{Mo}^{6+}$ ions 
(72 vs. $73 \mathrm{pm}$ ), no significant changes in the lattice parameter of $\mathrm{Mn}_{2} \mathrm{O}_{3}$ are expected upon Mo doping, thereby resulting in negligible diffraction angle shifts. At higher Mo loadings $\left(8.7-31 \% \mathrm{MoO}_{3}\right)$, a fraction of the Mo added ended up forming a new monoclinic $\mathrm{MnMoO}_{4}$ crystal phase (ICDD: 00-050-1287) with the main diffraction peak at $25.7^{\circ}$. The intensity of this peak increased with the Mo loading. The $100 \% \mathrm{MoO}_{3}$ sample showed a very different XRD pattern, characterized by a main peak at $27.4^{\circ}$. This pattern was ascribed to a $\mathrm{MoO}_{3}$ crystalline phase (ICDD: 00-001-0706). The diffraction peaks characteristics of this phase were not found for the rest of the samples, allowing us to rule out the presence of $\mathrm{MoO}_{3}$ in these materials. Unlike $\mathrm{MoO}_{3}$, the $\mathrm{Mn}$-Mo mixed oxide phases are thermally stable at $750{ }^{\circ} \mathrm{C}$ [28]. No characteristic peaks corresponding to $\mathrm{Mn}_{2} \mathrm{Mo}_{3} \mathrm{O}_{8}$ were revealed by XRD [23].

(a)

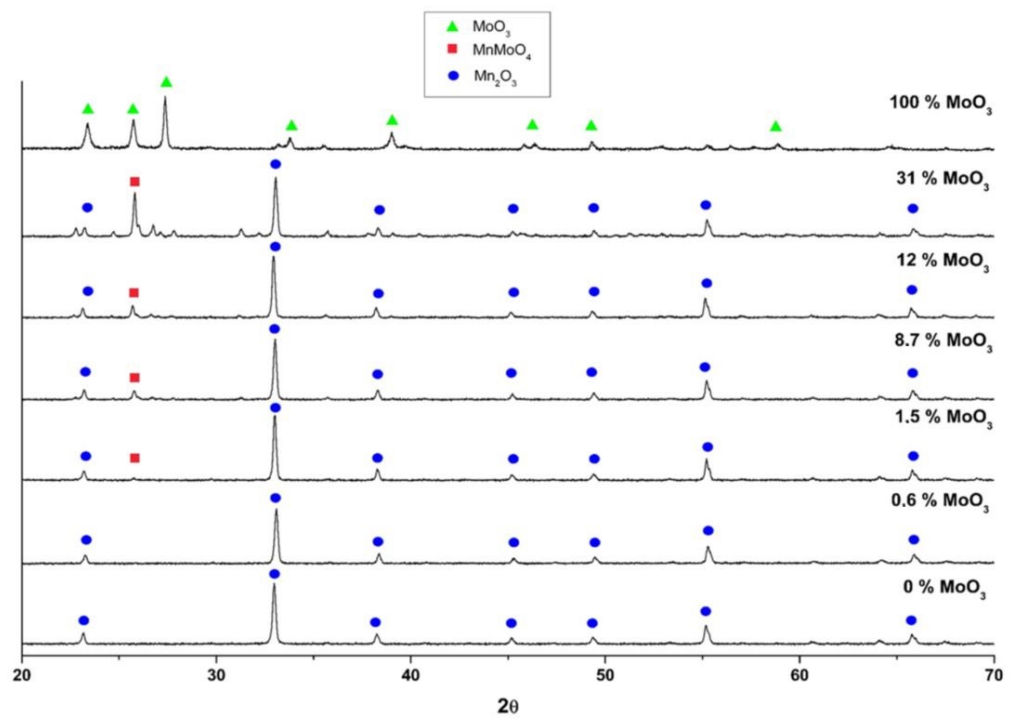

b)

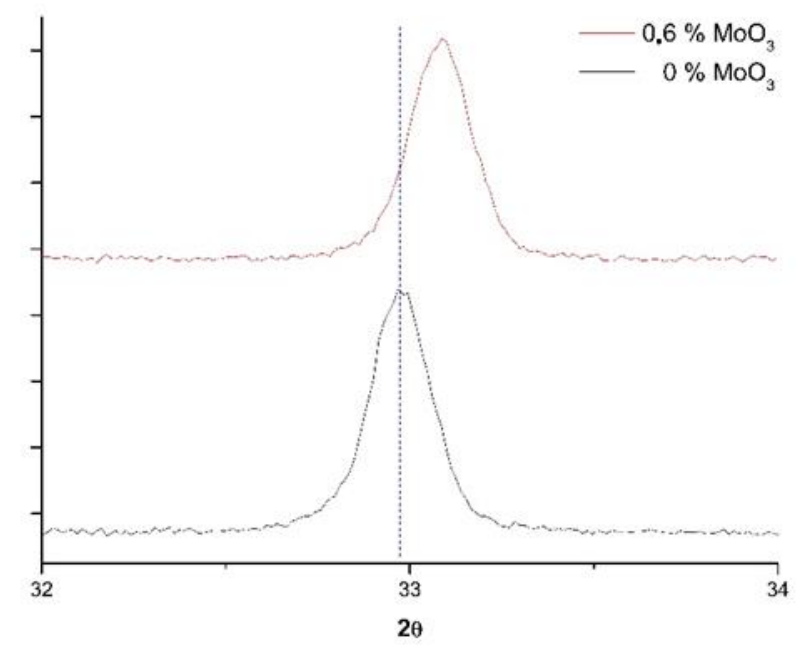

Figure 2. (a) $\mathrm{XRD}$ patterns for the $\mathrm{X} \%-\mathrm{MoO}_{3}$ samples. Three phases were identified: $\mathrm{Mn}_{2} \mathrm{O}_{3}$, $\mathrm{MnMoO}_{4}$, and $\mathrm{MoO}_{3}$. (b) Zoomed $2 \theta$ region $32-34^{\circ}$ for the samples $0 \% \mathrm{MnO}_{3}$ and $0.6 \% \mathrm{MnO}_{3}$.

The morphology of the materials was observed by SEM, and the most representative micrographs are shown in Figure 3a. Remarkably, all the samples except $30 \% \mathrm{MoO}_{3}$ showed a well-formed coral-like morphology. This coral-like morphology is believed to be key in facilitating oxygen diffusion during the redox process and in preventing excessive sintering of the material at high temperatures. However, as the amount of Mo increased in the samples, the micrographs revealed the presence of compact secondary particles 
(encircled in red in Figure 3a), which was more evident for the 8.7, 12, and 31\% $\mathrm{MoO}_{3}$ materials. We carried out energy-dispersive X-ray spectroscopy (EDS) analyses on our samples by performing elemental measurements at different spots of the SEM pictures (indicated by numbers in Figure 3a). The EDS spectra obtained for each of these spots are shown in Figure 3b. These analyses we aimed to confirm the presence of Mo in our samples. These analyses were performed over zones with coral-like morphologies. At these zones, we found Mo contents relatively close to the nominal loadings in all cases except for the $12 \% \mathrm{MoO}_{3}$ sample, which showed an unexpectedly low value. EDS also allowed us to compare the composition of compact secondary particles with that of the coral-like zones. As shown for the $1.5 \% \mathrm{MoO}_{3}$ sample (spots 3 and 4 in Figure $3 a, b$ ), the compact particle analyzed was enriched in Mo as compared to the coral-like zone, which showed a composition more similar to the nominal loading. This result seems to support the hypothesis that compact particles might correspond to $\mathrm{MnMoO}_{4}$, in line with XRD results. However, we note that these compositional analyses based on EDS are not fully representative of the totality of the samples and have a certain variability depending on the spot analyzed.

(a)
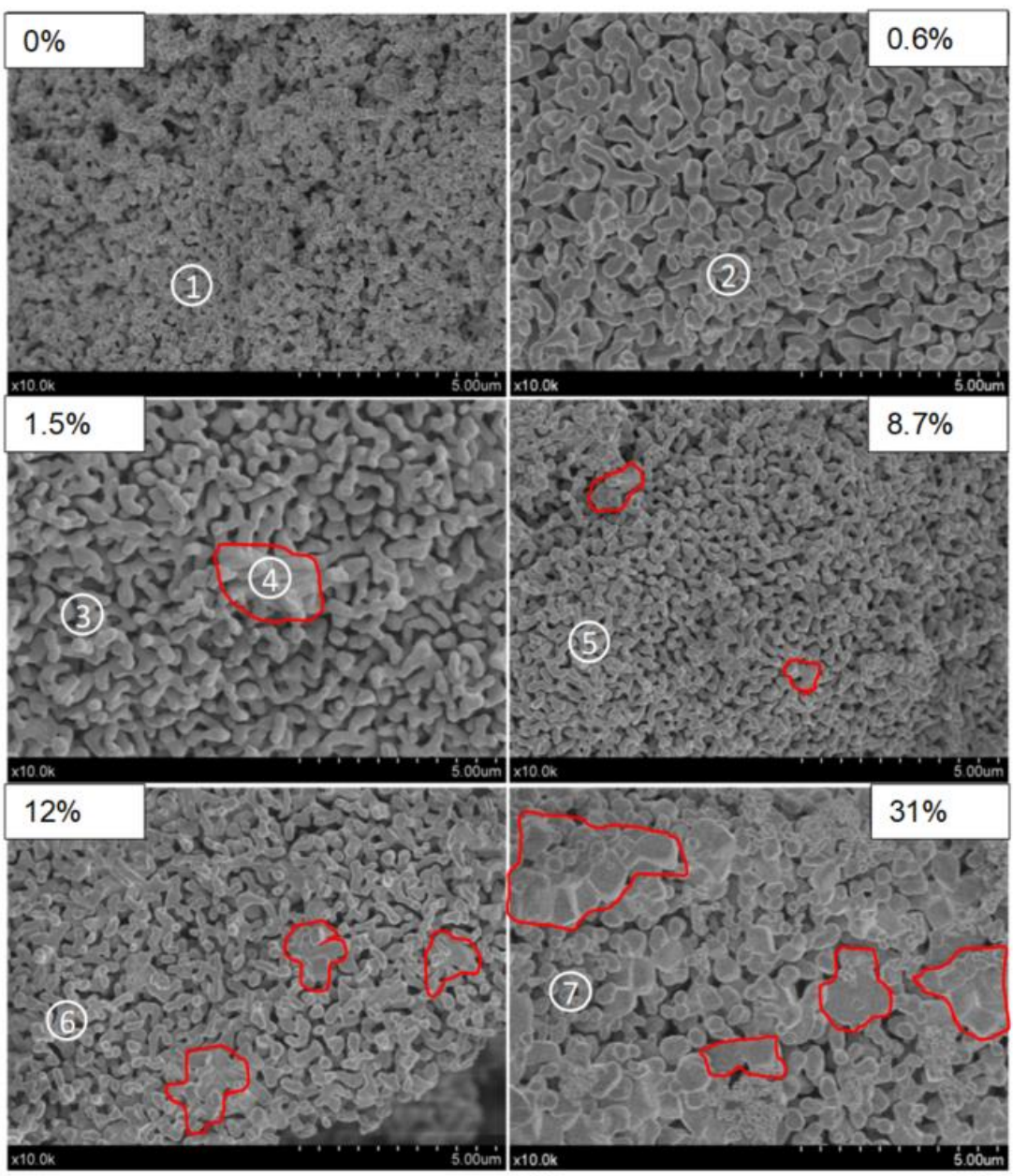

Figure 3. Cont. 

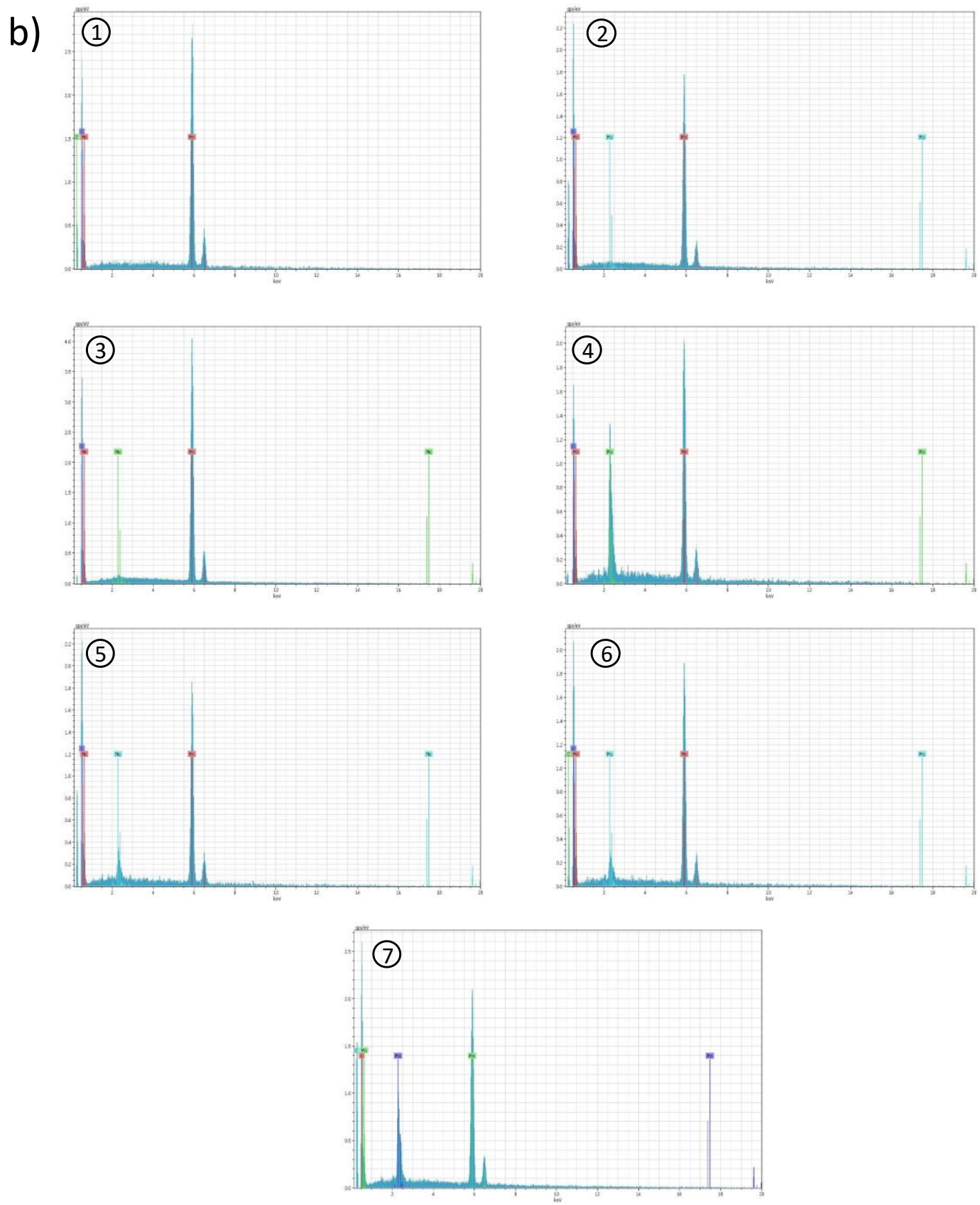

Figure 3. (a) SEM pictures of the different Mn-Mo materials studied herein. Some compact secondary particles are encircled in red for clarity. Numbers indicate the spots from which the EDS analyses were obtained. (b) EDS spectra corresponding to the spots of Figure 3a.

The TPR profiles of the samples under study are shown in Figure 4. The $0 \% \mathrm{MoO}_{3}$ sample showed a reduction profile similar to that previously reported for $\mathrm{Mn}_{2} \mathrm{O}_{3}$, with two reduction peaks at 250 and $400{ }^{\circ} \mathrm{C}[29,30]$. Considering the amount of hydrogen consumed, these peaks can be attributed to the successive reduction of $\mathrm{Mn}^{3+}$ to $\mathrm{Mn}\left({ }^{3+},{ }^{2+}\right)$ and finally to $\mathrm{Mn}^{2+}$. Interestingly, the addition of low amounts of $\mathrm{Mo}\left(0.6\right.$ and $\left.1.5 \% \mathrm{MoO}_{3}\right)$ changed dramatically the reduction profile of $\mathrm{Mn}_{2} \mathrm{O}_{3}$ from a double-peak to a single reduction peak centered at ca. $500{ }^{\circ} \mathrm{C}$. This dramatic change in the reduction profile suggests that Mo ions could be forming part of the structure of $\mathrm{Mn}_{2} \mathrm{O}_{3}$, strongly affecting the redox behavior of $\mathrm{Mn}^{3+}$. The replacement of $\mathrm{Mn}^{3+}$ with $\mathrm{Mo}^{6+}$ is expected to generate a charge imbalance in the $\mathrm{Mn}_{2} \mathrm{O}_{3}$ lattice, given the different oxidation states of the exchangeable ions. Thus, each $\mathrm{Mo}^{+6}$ ion introduced will generate a surplus of positive charges in the lattice. As a result, the $\mathrm{Mn}_{2} \mathrm{O}_{3}$ lattice is expected to generate certain crystalline defects (i.e., one $\mathrm{Mn}^{3+}$ 
vacancy for each $\mathrm{Mo}^{6+}$ ion exchanged) to offset the excess of positive charges. These cation vacancies can produce significant changes in the properties of $\mathrm{Mn}_{2} \mathrm{O}_{3}$ even with relatively low doping amounts. Thus, $\mathrm{Mn}^{3+}$ cation vacancies generated upon $\mathrm{Mo}^{+6}$ doping have been previously reported to result in significant changes in the morphology and redox behavior of manganese oxide materials [27]. As the amount of Mo increases in the samples (8.7-31\% $\mathrm{MoO}_{3}$ ), new broad reduction peaks appeared at temperatures higher than $600{ }^{\circ} \mathrm{C}$. These broad reduction peaks could be attributed to the reduction of the mixed phase $\mathrm{MnMoO}_{4}$, which was present in these samples according to the XRD patterns. Similar TPR profiles were reported by Cadus et al. for $\mathrm{Mn}_{2} \mathrm{O}_{3}$-supported molybdenum materials [31]. The $100 \%$ $\mathrm{MoO}_{3}$ sample showed a broad reduction signal between 550 and $700{ }^{\circ} \mathrm{C}$, the temperature at which sublimation was observed and the experiment was interrupted.

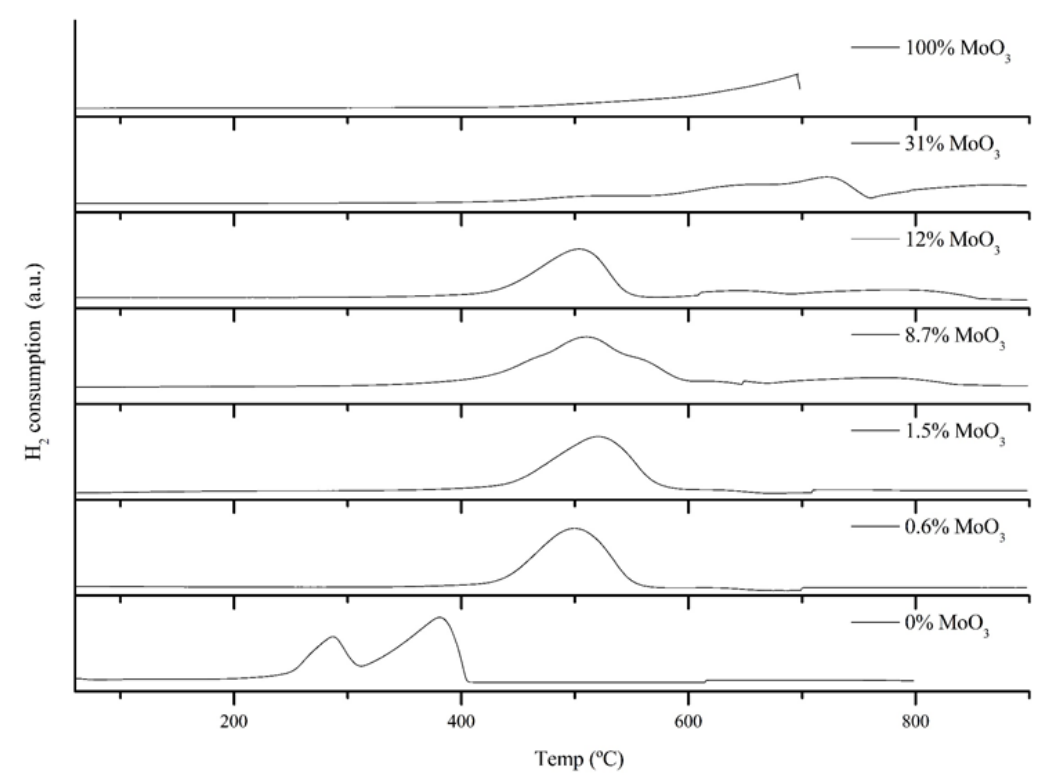

Figure 4. TPR profiles of the Mn-Mo samples under study. Experiments were conducted with $45 \mathrm{mg}$ of sample. $\mathrm{T}=60-900{ }^{\circ} \mathrm{C}\left(10^{\circ} \mathrm{C} / \mathrm{min}\right.$ heating rate). Constant $10 \% \mathrm{H}_{2} /$ Ar flow of $50 \mathrm{~mL} \mathrm{~min}{ }^{-1}$.

\subsection{Redox Cycling Behavior}

The redox behavior of the samples was studied by monitoring the losses and gains of weight after consecutive reduction-oxidation cycles, respectively (Figure 5). Thus, a weight loss was indicative of reduction $\left(\mathrm{O}_{2}\right.$ release, reduction, charge), whereas a weight gain was associated to oxidation $\left(\mathrm{O}_{2}\right.$ uptake, oxidation, discharge). As shown in Figure 5, pure $\mathrm{Mn}_{2} \mathrm{O}_{3}$ showed the poorest redox cyclability among the materials studied herein, with very low re-oxidation rates (i.e., slow weight gains). Both the oxidation kinetics and the thermal cyclability improved significantly upon addition of $\mathrm{Mo}$ to $\mathrm{Mn}_{2} \mathrm{O}_{3}$. Thus, the Mn-Mo samples showed complete reduction at temperatures below $1000^{\circ} \mathrm{C}$. As shown in Table 2, the weight loss of the samples decreased with the Mo content. We calculated the theoretical weight change considering only the actual amount of manganese in the mixed oxide (determined by ICP-AES, Table 1) and included those values in Table 2. Interestingly, the deviation from the theoretical value increased with the amount of Mo. Thus, the $8.7 \%$ $\mathrm{MoO}_{3}, 12 \% \mathrm{MoO}_{3}$, and $31 \% \mathrm{MoO}_{3}$ samples showed weight losses above their theoretical value, thereby suggesting that the $\mathrm{MnMoO}_{4}$ phase identified by XRD (Figure 2) possessed some redox activity, as suggested by the TPR profiles (Figure 4). 


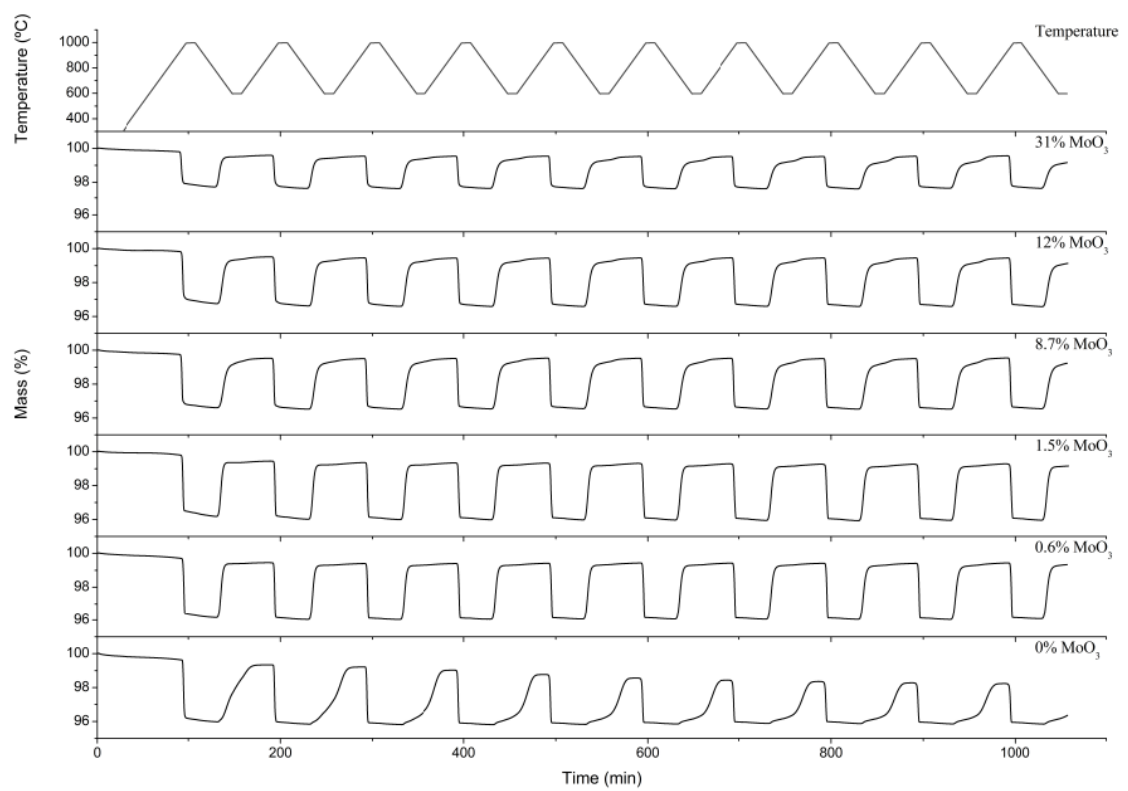

Figure 5. Thermal cycling behavior of the Mn-Mo samples under study for 10 consecutive reduction oxidation cycles.

Table 2. Theoretical (based on the Mn content) and TG-measured weight losses for the second reduction cycle for all the samples under study.

\begin{tabular}{cccc}
\hline Sample & Theoretical Weight Loss (\%) & Measured Weight Loss (\%) & Deviation (\%) \\
\hline $0 \% \mathrm{MoO}_{3}$ & 3.38 & 3.42 & 4 \\
$0.6 \% \mathrm{MoO}_{3}$ & 3.33 & 3.27 & -6 \\
$1.5 \% \mathrm{MoO}_{3}$ & 3.27 & 3.25 & -2 \\
$8.7 \% \mathrm{MoO}_{3}$ & 2.76 & 2.84 & +8 \\
$12 \% \mathrm{MoO}_{3}$ & 2.51 & 2.81 & +30 \\
$31 \% \mathrm{MoO}_{3}$ & 1.18 & 1.79 & +61 \\
$100 \% \mathrm{MoO}_{3}$ & - & - & \\
\hline
\end{tabular}

The $0.6 \% \mathrm{MoO}_{3}$ and $1.5 \% \mathrm{MoO}_{3}$ samples showed the best long-term redox cyclability among the samples studied herein, with no noticeable loss of reactivity after 10 consecutive redox cycles. These samples showed square reduction and oxidation profiles, which are indicative of a stable redox behavior. The addition of Mo above $1.5 \% \mathrm{MoO}_{3}$ did not enhance the oxidation rate, and a progressive loss of cyclability was observed as the amount of Mo increased in the samples. Thus, additional long-term cyclability tests were performed on the $0.6 \% \mathrm{MoO}_{3}$ and $1.5 \% \mathrm{MoO}_{3}$ samples. Figure 6 shows the weight losses of the reduction process for 45 consecutive redox cycles. After the first two cycles, both samples showed excellent cyclability, with no significant changes in the weight losses. The optimum long-term redox behavior of these samples could be ascribed to their corallike morphology (Figure 3). This morphology allows oxygen diffusion through the solid, thereby facilitating the reduction and oxidation processes. This coral morphology has been previously associated with optimum redox behavior in Mn-containing materials [32]. Interestingly, these samples showed lower surface areas than the rest of oxides (Table 1), which reveals that this parameter does not determine the redox behavior of these materials. The fact that pure $\mathrm{Mn}_{2} \mathrm{O}_{3}\left(0 \% \mathrm{MoO}_{3}\right)$ also showed a well-formed coral-like morphology and a poor oxidation rates is a strong indicator that Mo necessarily plays a role in improving the oxidation behavior of the $0.6 \% \mathrm{MoO}_{3}$ and $1.5 \% \mathrm{MoO}_{3}$ samples. For these samples, the shift of the main diffraction peak of $\mathrm{Mn}_{2} \mathrm{O}_{3}$ to higher angles (Figure 2) suggests that $\mathrm{Mo}^{6+}$ ions $(73 \mathrm{pm})$ were able to replace $\mathrm{Mn}^{3+}$ ions $(72 \mathrm{pm})$ in the $\mathrm{Mn}_{2} \mathrm{O}_{3}$ lattice, likely occupying six-fold octahedral coordination sites [25-27]. The poor oxidation behavior of 
pure $\mathrm{Mn}_{2} \mathrm{O}_{3}$ has been previously ascribed to the significant structural mismatches existing between the reduced $\left(\mathrm{Mn}_{3} \mathrm{O}_{4}\right.$, tetragonal or cubic spinels) and the oxidized $\left(\mathrm{Mn}_{2} \mathrm{O}_{3}\right.$, cubic) phases [8]. Thus, the transition from tetragonal $\mathrm{Mn}_{3} \mathrm{O}_{4}$ to cubic $\mathrm{Mn}_{2} \mathrm{O}_{3}$ involves large structural changes (e.g., lattice shrinking) and atomic rearrangements, which ultimately results in a sluggish oxidation process. The addition of $\mathrm{Fe}$ to $\mathrm{Mn}_{2} \mathrm{O}_{3}$ has been reported to improve the oxidation kinetics by promoting the formation of a cubic $\mathrm{Mn}_{3} \mathrm{O}_{4}$ phase, thereby allowing a smoother transition (from cubic to cubic) from the reduced to the oxidized materials [33]. The addition of low amounts of $\mathrm{Mo}\left(0.6 \% \mathrm{MoO}_{3}\right.$ and $\left.1.5 \% \mathrm{MoO}_{3}\right)$ could produce a similar effect in the reduced $\mathrm{Mn}_{3} \mathrm{O}_{4}$ phase, facilitating the transition from the reduced to the oxidized phases. The TPR profiles of these samples, with a single reduction peak instead of a double-peak profile for pure $\mathrm{Mn}_{2} \mathrm{O}_{3}$ (Figure 4), seem to support this hypothesis. As shown in Figure 5, the addition of Mo in amounts larger than 1.5\% $\mathrm{MoO}_{3}$ did not improve the oxidation behavior of $\mathrm{Mn}_{3} \mathrm{O}_{4}$, with the oxidation rate decreasing as the amount of Mo increased in the samples. The amount of monoclinic phase $\mathrm{MnMoO}_{4}$ in these samples also increased with the Mo loading (Figure 2), which suggests that this phase was not responsible for improving the oxidation behavior of the solids.

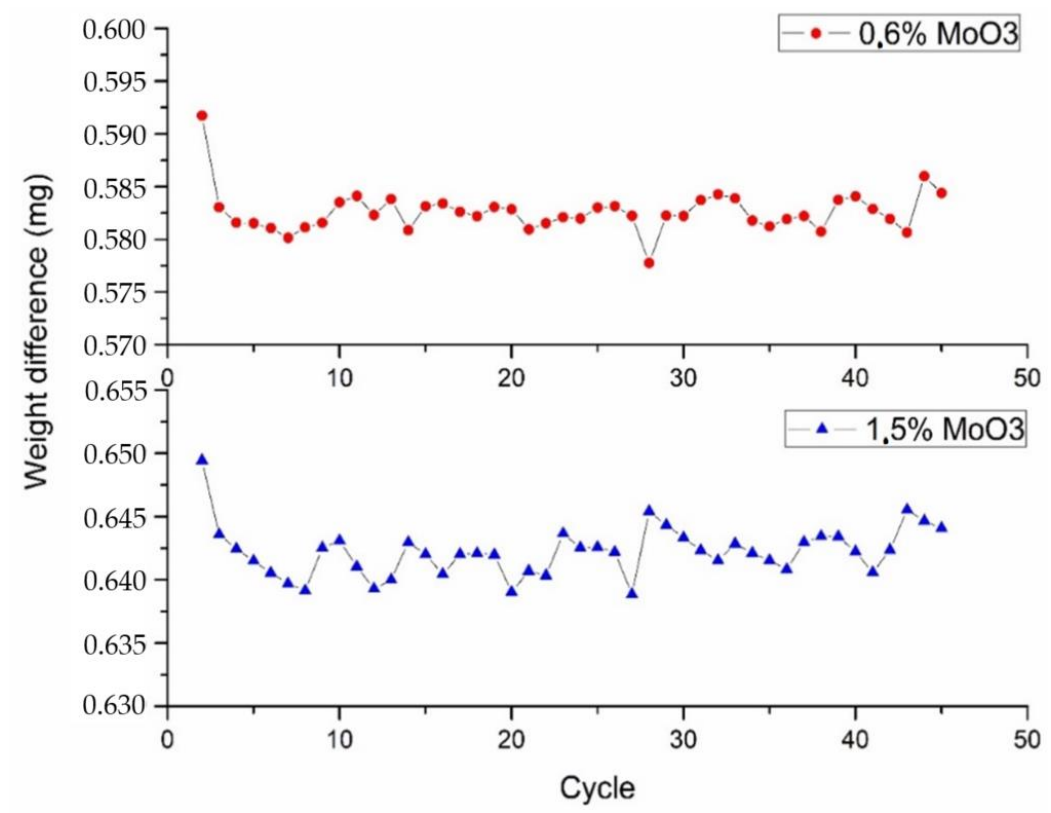

Figure 6. Long-term cyclability tests for the $0.6 \% \mathrm{MoO}_{3}$ and $1.5 \% \mathrm{MoO}_{3}$ samples.

Besides the weight variation (which is directly related with the storage capacity), the TES operational temperatures are also very important in determining the efficiency of thermal storage devices for CSP plants [34]. Thus, since reduction and oxidation take place at different temperatures (i.e., thermal hysteresis) for the Mn-Mo samples, heat is stored and released at different temperatures. This thermal hysteresis is one of the main factors affecting to the charge-discharge exergy efficiency, such that it is desirable that these temperatures are as similar as possible, which would result in higher exergy efficiencies [34]:

$$
\eta_{e x}=\frac{1-\frac{T_{c}}{T_{o x}}}{1-\frac{T_{c}}{T_{r e d}}}
$$

where $T_{r e d}$ and $T_{o x}$ are the temperatures at which reduction and oxidation processes take place, respectively, and $T_{c}$ is the cold reservoir temperature ( $\left.298 \mathrm{~K}\right)$. Table 3 summarizes the operational temperatures, the temperature hysteresis, and the charge-discharge exergy efficiency for the $0,0.6$, and $1.5 \%$ of $\mathrm{MoO}_{3}$ samples (for the redox cycles described in Figure 6). First of all, it is important to remark that the experimental temperatures are slightly higher than the one predicted by the thermodynamic study (Table 1) as result of the 
critical influence of diffusion and chemical kinetics in the process, which is not considered in the equilibrium calculations [35].

Table 3. Operational temperatures, hysteresis temperature, and charge-discharge exergy efficiency for the $0 \%$ (pure $\mathrm{Mn}_{2} \mathrm{O}_{3}$ ), $0.6 \%$, and $1.5 \%$ of $\mathrm{MoO}_{3}$ samples.

\begin{tabular}{|c|c|c|c|c|c|}
\hline Sample & Cycle & $T_{\text {red }}\left({ }^{\circ} \mathrm{C}\right)$ & $T_{o x}\left({ }^{\circ} \mathrm{C}\right)$ & $\Delta T\left({ }^{\circ} \mathrm{C}\right)$ & $\eta_{e x}(\%)$ \\
\hline $\mathrm{Mn}_{2} \mathrm{O}_{3}$ & 1 & 950 & 640 & 310 & 89.06 \\
\hline \multirow{4}{*}{$0.6 \% \mathrm{MoO}_{3}$} & 2 & 960 & 730 & 230 & 92.69 \\
\hline & 10 & 980 & 720 & 260 & 91.83 \\
\hline & 30 & 980 & 700 & 280 & 91.02 \\
\hline & 45 & 980 & 700 & 280 & 91.02 \\
\hline \multirow{4}{*}{$1.5 \% \mathrm{MoO}_{3}$} & 2 & 955 & 740 & 215 & 93.20 \\
\hline & 10 & 970 & 730 & 240 & 92.45 \\
\hline & 30 & 975 & 720 & 255 & 91.94 \\
\hline & 45 & 975 & 720 & 255 & 91.94 \\
\hline
\end{tabular}

Regarding the operational temperatures, the reduction temperature (i.e., the temperature at which maximum oxygen release rates are reached) increased with the cycle number, while the oxidation temperature (i.e., the temperature at which maximum oxygen uptake rates are reached) decreased upon thermal cycling for both samples, although this was more evident for the $1.5 \% \mathrm{MoO}_{3}$ sample. This fact implies that the higher the number of cycles the higher the temperature hysteresis, although this parameter seems to stabilize for both materials after the 30th cycle. Additionally, as the change in the operational temperatures is more evident for the $1.5 \% \mathrm{MoO}_{3}$ sample, it presents a higher decrease in the hysteresis temperature as compared to $\mathrm{Mn}_{2} \mathrm{O}_{3}$. Most importantly, the temperature hysteresis was significantly reduced (by $80-30$ and $95-55{ }^{\circ} \mathrm{C}$ ) for the $0.6 \% \mathrm{MoO}_{3}$ and $1.5 \% \mathrm{MoO}_{3}$ samples as compared to $\mathrm{Mn}_{2} \mathrm{O}_{3}$, respectively, thereby enhancing the charge-discharge efficiency of the cycle (by 3.6-2.0 and 4.1-3.0\%, respectively).

Additionally, the operational temperatures must be compatible with the working conditions of other parts of the CSP plants such as the solar concentrator (which must concentrate the solar radiation to achieve the required temperatures) and the receiver (where the reactions take place). If we assumed that the solar reactor is a perfectly insulated blackbody receiver, the absorption efficiency is given by Equation (5) [36]:

$$
\eta_{\mathrm{abs}}=1-\frac{\sigma \cdot T_{\text {reactor }}^{4}}{I \cdot C}
$$

where $\sigma$ is the Stefan-Boltzmann constant $\left(5.67 \cdot 10^{-11} \mathrm{~kW} / \mathrm{m}^{2} \cdot \mathrm{K}^{4}\right) ; T_{\text {reactor }}$ is the solar reactor temperature $\left(T_{\text {red }}\right)$; I is the direct-normal solar irradiation (taken as $\left.1 \mathrm{~kW} \cdot \mathrm{m}^{2}\right)$; $C$ is the concentration ratio which is defined as the solar radiative flux normalized to $1 \mathrm{~kW} / \mathrm{m}^{2}$ and is usually expressed in "suns" units. Table 4 summarizes the absorption efficiency for 0.6 and $1.5 \%$ of $\mathrm{MoO}_{3}$ samples for the different cycles as a function of the concentration ratio of the solar concentrator. Although the temperature hysteresis is different for both materials, the absorption efficiency was almost similar and higher than $90 \%$ when the concentration capacity is higher than 2000 suns, which indicates that the operational temperatures of these materials are compatible with current solar technology, and that these materials are promising for large-scale thermochemical heat storage applications. 
Table 4. Solar receiver absorption efficiencies for the $0.6 \%$ and $1.5 \% \mathrm{MoO}_{3}$ samples.

\begin{tabular}{|c|c|c|c|c|c|c|}
\hline \multirow{2}{*}{ Sample } & \multirow{2}{*}{ Cycle } & \multicolumn{5}{|c|}{$\eta_{\text {abs }}(\%)$} \\
\hline & & $C=1000$ & $C=2000$ & $C=3000$ & $C=4000$ & $C=5000$ \\
\hline \multirow{4}{*}{$\begin{array}{c}0.6 \% \\
\mathrm{MoO}_{3}\end{array}$} & 2 & 86.90 & 93.45 & 95.63 & 96.72 & 97.38 \\
\hline & 10 & 86.02 & 93.01 & 95.34 & 96.51 & 97.20 \\
\hline & 30 & 86.02 & 93.01 & 95.34 & 96.51 & 97.20 \\
\hline & 45 & 86.02 & 93.01 & 95.34 & 96.51 & 97.20 \\
\hline \multirow{4}{*}{$1.5 \% \mathrm{MoO}_{3}$} & 2 & 87.11 & 93.55 & 95.70 & 96.78 & 97.42 \\
\hline & 10 & 86.46 & 93.23 & 95.49 & 96.62 & 97.29 \\
\hline & 30 & 86.25 & 93.12 & 95.42 & 96.56 & 97.25 \\
\hline & 45 & 86.25 & 93.12 & 95.42 & 96.56 & 97.25 \\
\hline
\end{tabular}

\section{Conclusions}

The addition of small amounts of Mo to $\mathrm{Mn}_{2} \mathrm{O}_{3}$ was found to improve the TCS behavior (e.g., oxidation kinetics and redox cyclability) of this oxide without significantly increasing its reduction temperature. XRD suggested that most of the Mo added ended up forming a separate monoclinic phase $\mathrm{MoMnO}_{4}$, while only a limited fraction of the Mo ions were inserted in the cubic $\mathrm{Mn}_{2} \mathrm{O}_{3}$ structure. Despite the limited extent of this substitution, the presence of $\mathrm{Mo}^{6+}$ ions in the structure changed dramatically the redox behavior of $\mathrm{Mn}_{2} \mathrm{O}_{3}$, as revealed by TPR. SEM observations revealed a coral-like morphology, particularly for samples with low Mo loadings. Mo-enriched compact particles and a partial collapse of the coral-like structure were observed for Mo loadings above $8.7 \% \mathrm{MoO}_{3}$. The 0.6 and $1.5 \% \mathrm{MoO}_{3}$ samples showed excellent long-term (45 cycles) TCS behavior, with fast oxidation processes and outstanding cyclability. These samples also showed lower temperature hysteresis as compared to $\mathrm{Mn}_{2} \mathrm{O}_{3}$, which resulted in higher exergy charge-discharge efficiencies. The operational temperatures of the $\mathrm{Mn}-\mathrm{Mo}$ materials prepared herein were compatible with those typical of solar receivers, potentially reaching absorption efficiencies higher than $90 \%$ at concentration capacity values typical of CSP plants.

Author Contributions: Conceptualization, J.M. (Javier Marugán) and J.C.S.-R.; methodology, J.M. (Javier Moya), M.O., M.A.D.-P.; formal analysis, J.M. (Javier Moya), M.O., M.A.D.-P.; investigation, J.M. (Javier Moya), M.O., M.A.D.-P.; resources, J.M. (Javier Marugán), J.C.S.-R.; writing—original draft preparation, J.M. (Javier Moya), M.O., M.A.D.-P.; writing-review and editing, J.M. (Javier Marugán), J.C.S.-R.; funding acquisition, J.M. (Javier Marugán), J.C.S.-R. All authors have read and agreed to the published version of the manuscript.

Funding: This research was funded by Ramón y Cajal Program, Grant: RYC-2015-19230.

Institutional Review Board Statement: Not applicable.

Informed Consent Statement: Not applicable.

Data Availability Statement: Not applicable.

Acknowledgments: J.C.S.-R. would like to thank the Spanish Ministry of Science and Innovation for financial support through the Ramón y Cajal Program, Grant: RYC-2015-19230. J.C.S.-R. would also like to thank Junta de Andalucía for financial support through the projects PY18-RE-0012 and the "Carbocat" project IE18_0047_FUNDACIÓN LOYOLA.

Conflicts of Interest: The authors declare no conflict of interest.

Sample Availability: Samples of the mixed oxides are available from the authors.

\section{References}

1. BP. BP Energy Outlook. Available online: https://www.bp.com/en/global/corporate/energy-economics/energy-outlook.html (accessed on 22 January 2021). 
2. Foley, T.; Thornton, K.; Hinrichs-rahlwes, R.; Sawyer, S.; Sander, M.; Taylor, R.; Teske, S.; Lehmann, H.; Alers, M.; Hales, D. Renewables 2015: Global Status Report; REN21: Paris, France, 2015. Available online: https:/ /www.ren21.net/wp-content/uploads/ 2019/05/GSR2015_Full-Report_English.pdf (accessed on 22 January 2021).

3. Liu, M.; Steven Tay, N.H.; Bell, S.; Belusko, M.; Jacob, R.; Will, G.; Saman, W.; Bruno, F. Review on concentrating solar power plants and new developments in high temperature thermal energy storage technologies. Renew. Sustain. Energy Rev. 2016, 53, 1411-1432. [CrossRef]

4. Yekini Suberu, M.; Wazir Mustafa, M.; Bashir, N. Energy storage systems for renewable energy power sector integration and mitigation of intermittency. Renew. Sustain. Energy Rev. 2014, 35, 499-514. [CrossRef]

5. Zhang, H.; Baeyens, J.; Cáceres, G.; Degrève, J.; Lv, Y. Thermal energy storage: Recent developments and practical aspects. Prog. Energy Combust. Sci. 2016, 53, 1-40. [CrossRef]

6. Pardo, P.; Deydier, A.; Anxionnaz-Minvielle, Z.; Rougé, S.; Cabassud, M.; Cognet, P. A review on high temperature thermochemical heat energy storage. Renew. Sustain. Energy Rev. 2014, 32, 591-610. [CrossRef]

7. Abedin, A.H.; Rosen, M.A. Closed and open thermochemical energy storage: Energy- and exergy-based comparisons. Energy 2012, 41, 83-92. [CrossRef]

8. Carrillo, A.J.; Serrano, D.P.; Pizarro, P.; Coronado, J.M. Improving the thermochemical energy storage performance of the $\mathrm{Mn}_{2} \mathrm{O}_{3} / \mathrm{Mn}_{3} \mathrm{O}_{4}$ redox couple by the incorporation of iron. Chem. Sus. Chem. 2015, 8, 1947-1954. [CrossRef]

9. Gliech, M.; Bergmann, A.; Spöri, C.; Strasser, P. Synthesis-structure correlations of manganese-cobalt mixed metal oxide nanoparticles. J. Energy Chem. 2016, 25, 278-281. [CrossRef]

10. PROJECT STAFF. General Atomics Thermochemical Heat Storage for Concentrated Solar Power, Thermochemical System Reactor Design for Thermal Energy Storage; DOE/GO18145 TRN: US201209\%\%526; OSTI.GOV: San Diego, CA, USA, 2011. Available online: https: / / www.osti.gov/servlets/purl/1039304 (accessed on 22 January 2021).

11. Agrafiotis, C.; Roeb, M.; Sattler, C. Exploitation of thermochemical cycles based on solid oxide redox systems for thermochemical storage of solar heat. Part 4: Screening of oxides for use in cascaded thermochemical storage concepts. Sol. Energy 2016, 139, 695-710. [CrossRef]

12. Licurgo, J.; Fuentealba, E.; Alonso, E.; Pe, C.; Estrada, C.A. First experimental studies of solar redox reactions of copper oxides for thermochemical energy storage. Sol. Energy 2015, 115, 297-305.

13. Block, T.; Schmücker, M. Metal oxides for thermochemical energy storage: A comparison of several metal oxide systems. Sol. Energy 2016, 126, 195-207. [CrossRef]

14. Bowrey, R.G.; Jutsen, J. Energy storage using the reversible oxidation of barium oxide. Sol. Energy 1978, 21, 523-525. [CrossRef]

15. Fahim, M.A.; Ford, J.D. Energy storage using the $\mathrm{BaO}_{2}-\mathrm{BaO}$ reaction cycle. Chem. Eng. J. 1983, 27, 21-28. [CrossRef]

16. Carrillo, A.J.; Sastre, D.; Serrano, D.P.; Pizarro, P.; Coronado, J. Revisiting the BaO2/BaO redox cycle for solar thermochemical energy storage. Phys. Chem. Chem. Phys. 2016, 18, 8039-8048. [CrossRef]

17. Carrillo, A.J.; Moya, J.; Bayón, A.; Jana, P.; De, V.A.; Shea, P.O.; Romero, M.; Gonzalez-aguilar, J.; Serrano, D.P.; Pizarro, P.; et al. Thermochemical energy storage at high temperature via redox cycles of $\mathrm{Mn}$ and Co oxides: Pure oxides versus mixed ones. Sol. Energy Mater. Sol. Cells 2014, 123, 47-57. [CrossRef]

18. Block, T.; Knoblauch, N.; Schmücker, M. The cobalt-oxide/iron-oxide binary system for use as high temperature thermochemical energy storage material. Acta 2014, 577, 25-32. [CrossRef]

19. Agrafiotis, C.; Roeb, M.; Schmücker, M.; Sattler, C. Exploitation of thermochemical cycles based on solid oxide redox systems for thermochemical storage of solar heat. Part 2: Redox oxide-coated porous ceramic structures as integrated thermochemical reactors/heat exchangers. Sol. Energy 2015, 102, 189-211. [CrossRef]

20. Carrillo, A.J.; Serrano, D.P.; Pizarro, P.; Coronado, J.M. Manganese oxide-based thermochemical energy storage: Modulating temperatures of redox cycles by Fe-Cu co-doping. J. Energy Storage 2016, 5, 169-176. [CrossRef]

21. Wokon, M.; Block, T.; Nicolai, S.; Linder, M.; Schmücker, M. Thermodynamic and kinetic investigation of a technical grade manganese-iron binary oxide for thermochemical energy storage. Sol. Energy 2017, 153, 471-485. [CrossRef]

22. Wokon, M.; Kohzer, A.; Linder, M. Investigations on thermochemical energy storage based on technical grade manganese-iron oxide in a lab-scale packed bed reactor. Sol. Energy 2017, 153, 200-214. [CrossRef]

23. Wiesner, U.; Reichelt, W.; Krabbes, G. Stability Fields in the System Mn-Mo-O and Thermochemical Data of Mn2Mo3O8 and $\mathrm{MnMoO}_{4}$. Z. Anorg. Allg. Chem. 1987, 551, 67-73. [CrossRef]

24. Bessergenev, V.G.; Kovalevskaya, Y.A.; Paukov, I.E.; Starikov, M.A.; Oppermann, H.; Reichelt, W. Thermodynamic properties of $\mathrm{MnMoO}_{4}$ and $\mathrm{Mn}_{2} \mathrm{Mo}_{3} \mathrm{O}_{8}$. J. Chem. 1992, 24, 85-98. [CrossRef]

25. Shannon, R.D. Revised Effective Ionic Radii and Systematic Studies of Interatomie Distances in Halides and Chaleogenides. Acta Cryst. 1976, 32, 751-767. [CrossRef]

26. Allred, A.L. Electronegativity values from thermochemical Data. J. Inorg. Nucl. Chem. 1961, 17, 215-221. [CrossRef]

27. Chen, C.H.; Njagi, E.C.; Chen, S.Y.; Horvath, D.T.; Xu, L.; Morey, A.; Mackin, C.; Joesten, R.; Suib, S.L. Structural Distortion of Molybdenum-Doped Manganese Oxide Octahedral Molecular Sieves for Enhanced Catalytic Performance. Inorg. Chem. 2015, 54, 10163-10171. [CrossRef] [PubMed]

28. Medvedev, A.S.; Malochkina, N. V Sublimation of Molybdenum Trioxide from Exhausted Catalysts Employed for the Purification of Oil Products. Russ. J. Non-Ferr. Met. 2007, 48, 114-117. [CrossRef] 
29. Stobbe, E.R.; de Boer, B.A.; Geus, J.W. The reduction and oxidation behaviour of manganese oxides. Catal. Today 1999, 47, 161-167. [CrossRef]

30. Leith, I.R.; Howden, M.G. Temperature-programmed reduction of mixed iron-manganese oxide catalysts in hydrogen and carbon monoxide. Appl. Catal. 1988, 37, 75-92. [CrossRef]

31. Cadus, L.E.; Ferretti, O. Characterization of Mo-MnO catalyst for propane oxidative dehydrogenation. Appl. Catal. A Gen. 2002, 233, 239-253. [CrossRef]

32. Carrillo, A.J.; Serrano, D.P.; Pizarro, P.; Coronado, J.M. Thermochemical heat storage based on the $\mathrm{Mn}_{2} \mathrm{O}_{3} \mathrm{Mn}_{3} \mathrm{O}_{4}$ redox couple: Influence of the initial particle size on the morphological evolution and cyclability. J. Mater. Chem. A 2014, 2, 19435-19443. [CrossRef]

33. Azimi, G.; Leion, H.; Rydén, M.; Mattisson, T.; Lyngfelt, A. Investigation of different Mn-Fe oxides as oxygen carrier for chemical-looping with oxygen uncoupling (CLOU). Energy Fuels 2013, 27, 367-377. [CrossRef]

34. Weinstein, L.A.; Loomis, J.; Bhatia, B.; Bierman, D.M.; Wang, E.N.; Chen, G. Concentrating Solar Power. Chem. Rev. 2015, 115, 12797-12838. [CrossRef] [PubMed]

35. Marugán, J.; Botas, J.A.; Molina, R.; Herradón, C. Study of the first step of the $\mathrm{Mn}_{2} \mathrm{O}_{3} / \mathrm{MnO}$ thermochemical cycle for solar hydrogen production. Int. J. Hydrog. Energy 2011, 37, 7017-7025. [CrossRef]

36. Parrott, J.E. Choice of an equivalent black body solar temperature. Sol. Energy 1993, 51, 195. [CrossRef] 